\title{
The Link between Leadership Style, Organizational Change Perceptions and Job Satisfaction at the Ethiopian Electric Utility
}

\author{
Befekadu Zeleke* and Belayneh Kifle**
}

\begin{abstract}
This study explored the relationship between leadership style, employees' change perception, and job satisfaction at the Ethiopian Electric Utility. A correlation research design was used to conduct the study. The sample was composed of 40 leaders and 270 employees selected using proportionate stratified random sampling. Data were gathered using three standardized questionnaires merged into one and analyzed using both descriptive statistics such as mean, SD, and inferential statistics like Pearson product-moment correlation, an independent $t$ test, and MANOVA. Finally, the findings unveiled significant and positive correlations between transformational leadership style and organizational change perceptions and between transactional leadership style and intrinsic and extrinsic job satisfaction. There was also a negative correlation between organizational change and employees' job satisfaction. Furthermore, the transformational leadership style has emerged as the strongest predictor of employees' change perception. It was concluded that leaders at the organization ought to improve their leadership style to improve the existing employees' perception of change and their job satisfaction. Additional policy implications are also forwarded in the study.
\end{abstract}

Keywords: Job Satisfaction, Organizational Change, Transformational Leadership, Transactional Leadership, Laissez-faire Leadership DOI: https://dx.doi.org/10.1314/ejossah.v16i2.2

${ }^{*}$ Corresponding author: Associate Professor, Department of Educational Planning and Management, Addis Ababa University, Email: befekaduzk@gmail.com, Tel: +251911144218, P.O. Box 1176/ Addis Ababa

**Staffer, the Ethiopian Electric utility 


\section{Introduction}

The field of leadership has been widely explored and studied by many in terms of its different types and their applications (Avolio \& Yammarino, 2002; Buon, 2014). As such, research on leadership and organization has continued and received much attention today (Holten \& Brenner, 2015; Buon, 2014).

Leadership style is a series of attitudes, characteristics, and skills used by a leader in different situations in accordance with individual and organizational values (Mosadegh, 2006). The use of a particular leadership style affects both job satisfaction and productivity of employees (Nazarian et al., 2017). According to these researchers, research on leadership styles has gained much attention over a period of time. Leaders use different styles in different situations with different subordinates to motivate them to perform at their utmost potential. Leadership theories have proposed several leadership styles such as: autocratic, also known as authoritarian leadership, which is characterized by individual control over all decisions and little input from group members; bureaucratic leadership style that refers to organizational leadership through a highly formalized set of processes, procedures, and structures; laissez-faire leadership style also known as delegative leadership, is a type of leadership style in which leaders are hands-off and allow group members to make the decisions; charismatic leadership style that relies on the charm and persuasiveness of the leader; democratic or participative leadership, a type of leadership style in which members of the group take a more participative role in the decision-making process; situational leadership that holds no single leadership style is best instead, the best depends on which type of leadership and strategies are best-suited to the task; transactional leadership which is primarily based on processes of give and take, and requires a strict management structure while transformational leadership focuses on inspiring others to follow, and it requires a high degree of coordination, communication and cooperation. But there is a consensus among researchers that a single leadership style is not ideal for every situation (Northouse, 2016). And a leader may be more effective in a particular situation but may not emerge as effective in a different situation (Mosad and Yarmohammadian, 2006). A leadership style is a tool that provides a clear direction and path to enable employees to make their skills and performances more effective (Lee and Chuang, 2003). Different studies indicate that the behavior or the style of a leader is linked to different aspects of organizations such as employees' job satisfaction, their performances, and commitment during the implementation of change (Hassan, 2019).

For a successful organization, change is meant to be implemented at three different levels, i.e., individual, group, and organization. At every level of change, 
leadership plays a significant role as it's the virtual duty of a leader to manage people in an organization. Successful change in any organization is impossible without the active participation of the leadership. Every human being is reluctant to change, whether it is planned or accidental. Respondents to change are affected by both external and internal factors. Among these internal factors, the leadership style and leadership that influence the process of change are the major ones (Chirimbu, 2011). According to Smith (2005), people, the human resources of organizations, are both essential factors in organizational change and, at times, the biggest obstacles to achieving change. Leaders are the champions of change who keep the process of change going on and maintaining the operational reliability of the organization.

An organization's leadership style is considered to have a direct impact on the relations between leaders and an employee, thus affecting both the latter's performance, job satisfaction, and the organization's total coherence (Wilderom et al., 2004). Moreover, a study by Mckinnon et al (2003) has shown that in organizations that are flexible and adopt a participative leadership style, with an emphasis on communication and employees' reward, the latter is more likely to be satisfied, resulting in the organization's success.

In general, according to Bogler (2001), failure to engage in a suitable leadership style would lead to a subordinate's action to be dysfunctional rather than becoming productive and satisfied. On the other hand, Spector (1985) found that if employees find their job fulfilling and rewarding, they tend to be more satisfied with their jobs. Theoretical and empirical support for the influence of leadership styles and job satisfaction has been reported in several studies undertaken in different countries in a variety of organizational contexts. Ozer and Tinaztepe (2014) for instance conducted a study to examine how transformational and transactional leaders have the highest good impact on a firm's performance. The result from Morales et al. (2012) further disclosed that transformational leadership influences organizational performance positively through organizational learning and innovation. They concluded that transformational leadership is needed for organizations to improve their performance in changing real-life business environments. Emery and Barker (2015) further note that transformational leaders positively increase employees' satisfaction and sense of accomplishment with their job.

Voon and others (2011) on their part conducted a study to examine the relationship between leadership styles and job satisfaction in the public sector in Selangor, Malaysia. The results showed that transformational leadership style had a greater relationship with job satisfaction than transactional leadership. 
Befekadu Zeleke and Belayneh Kifle

Leadership style influences the well-being of followers (Skakon et al., 2010). This is also true during the time of organizational change where leaders play key roles as change agents (Kieselbach et al., 2009). Employees' positive reactions towards organizational change are produced if the leadership is competent enough and is perceived as fair by coworkers in an organization (Oreg et al., 2011). According to some findings, transformational leadership is an appropriate leadership style for dealing with organizational change (Bass and Riggio, 2006). Besides, transformational leadership facilitates how followers handle change in an organization and boost followers' commitment, self-efficacy, and empowerment during change (Bommer et al., 2005). A study by Oreg et al., (2011) reported that transformational leadership positively affects followers' reactions to organizational change. Similarly, a study by Holten \& Brenner (2015) has also proved that transformational leadership had a positive, long-term effect on followers' appraisal of change.

Different studies have also indicated that change affects employees' job satisfaction. This is because major programs of change require changes in the way people work or behave in an organization (Miller, 2002). Organizational change always entails new conditions that create anxiety, uncertainty, and stress, including among those leading the changes (Innstrand et al., 2004). As different studies indicate, the increase of uncertainty surrounding the changes is associated with a rise in stress levels and a decrease in satisfaction and commitment (Hui \& Lee, 2000). According to Glasby \& Lester (2004), organizational changes result in increasing levels of job dissatisfaction and reduced morale due to increased uncertainty during the process of change.

In general, although there are different research findings on the relationship between leadership styles and organizational change, leadership style and job satisfaction, and organizational change and job satisfaction separately, studies conducted to simultaneously examine the link between these three dimensions are lacking. Therefore, the purpose of this study is to assess the relationship between leadership style, change perceptions', and employees' job satisfaction at the Ethiopian Electric Utility.

\section{Statement of the problem}

Lack of leadership concentration on the complexity of change poorly developed strategy and structures and least attention towards people behavior and change make the process of change leadership ineffective. Organizational change and reorganizations may influence job and organizational characteristics and, as a result, job satisfaction. Organizational change can take different forms: 
reorganizing the work practices, job redesign, organizational growth, organizational downsizing. An organizational change aimed at a more businesslike attitude requires a major transformation of the organizational culture. This affects motivation and cooperation between workers. Noblet et al. (2006) show that introducing private-sector leadership strategies in public sector organizations results in structural, cultural, and procedural changes that had negative effects on job satisfaction.

An organization's specific culture can make change easier or harder, can affect the way change is communicated, and can impact the overall effectiveness of change. Traditional organizations do not generally adapt well to change; they may resist until well after the change is necessary and may fail to implement change effectively (Schein, 2004).

The Ethiopian Electric Utility has made two changes: Business Process Reengineering (BPR) in 2009 and Organizational Transformation in 2013. However, there are a lot of customer complaints and employee turnover, and low quality of services (Esayas, 2013). This shows that there is a knowledge gap in the relationship among the three leadership styles (transformational, transactional, and laissez-faire), change, and job satisfaction factors (intrinsic and extrinsic). These conditions made this research necessary to be conducted in the organization, to see the level of employees' job satisfaction and their change perceptions in relation to leadership style in the organization.

However, studies conducted to simultaneously examine the links between these three important elements are scant from the Ethiopian context. Yet, some studies have tried to examine part of these three elements. One of these studies was conducted in leather companies by Bekele and Darshan on the relationship between leadership styles and job satisfaction in 2011. The findings unveiled that only two of the transformational leadership dimensions (idealized influence and individualized consideration) had significant effects on the job satisfaction of employees (Bekele and Darshan, 2011).

Another study was conducted at the College of Education and Behavioral Studies of Addis Ababa University in 2010 by Fekadu. His findings showed a significant relationship between transformational and laissez-faire leadership styles and job satisfaction of academic staff. However, there was no observed relationship between transformational leadership and intrinsic job satisfaction (Fekadu, 2010).

Still another study was conducted by Nebiat and Asresash at Jima University specialized hospital. The findings showed that job satisfaction was more related to 
Befekadu Zeleke and Belayneh Kifle

transformational leadership than transactional leadership styles (Nebiat and Asresash, 2013).

In relation to employees' reaction to organizational change, a study was conducted at Ethiopian Revenue and Customs Authority by Genet in 2015. The findings indicated that perceived organizational support perceived procedural justice, perceived self-confidence in learning and development, perceived trust in management, and perceived need for change had a negative and significant effect on resistance to change while it had a positive and significant effect on support to change.

However, none of these studies have tried to simultaneously examine the links between the three leadership styles with employees' satisfaction and their change perceptions from the Ethiopian context. Hence, this study is conducted to fill in this knowledge gap. The study is also guided by the following research questions:

1. Is there any relationship between leadership styles and employees' perception of change?

2. Is there any relationship between leadership styles and employees' job satisfaction?

3. Is there any relationship between employees' perception of change and their job satisfaction?

4. Are there any relationships among leadership styles, organizational change perceptions, and employees' job satisfaction?

\section{Operational definitions}

Leadership style is a pattern of behavior leaders prefer to use and rated by respondents using Multi-factor Leadership Questionnaires (MLQ).

Organizational change perception refers to employees' perception of change as rated by respondents using the Organizational Change Recipients Beliefs' Scale Questionnaire.

Job satisfaction refers to employees' level of job satisfaction as rated by respondents using a job satisfaction survey (JSS) questionnaire.

\section{Review of the literature}

\section{Leadership styles}

The issue of leadership behavior or style as an important factor in determining leadership effectiveness began with behavioral studies in the 1950s. Particularly, different studies carried out in the USA during this period (Ohio, Michigan, and Iowa studies) came up with a conclusion that in addition to personality qualities 
(which was considered as an important factor for the traits approach) of the leader, his/her behavior in the workplace is crucial for leadership effectiveness. Following the behavioral studies, the contingency theories came in the 1960s and added the situation under which leadership is exercised as an important factor to determine leadership effectiveness. One of the current and most popular approaches to leadership that has been the focus of much research since the early 1980s following the situational approach is the transformational and transactional leadership styles focusing on leadership during the time of change (Northhouse, 2016). One of the most well-known formats to classify and study leadership focuses on three leadership styles: laissez-faire, transactional, and transformational (Koech \& Namusonge, 2012).

According to Marks and Printy (2003), transactional and transformational leadership form a new paradigm for understanding leadership styles. This paradigm builds on earlier sets of autocratic versus democratic or directive versus participative leadership (Avolio and Bass, 2004).

\section{Transformational leadership}

Concerning today's complex organizations and dynamic business environment, transformational leaders are often seen as ideal agents of change who could lead followers in times of uncertainties and high risk-taking. James MacGregor Burns (1978) conceptualized leadership as either transactional or transformational. Much of the literature is devoted to describing transformational leaders as leaders that provide a vision and a sense of mission, inspire, pride, and gain respect and trust through charisma (Bass, 1990). Stone et al. (2003) further state that transformational leadership has become very popular in recent years.

Transformational leaders seek to align followers' aspirations and needs with anticipated organizational outcomes. In so doing, transformational leaders can foster followers' commitment to organizations and inspire them to exceed their expected performance (Bass \& Riggio, 2006). Bass \& Riggio (2006) identified four dimensions of transformational leadership: idealized influence, inspirational motivation, intellectual stimulation, and individualized consideration.

Idealized influence is understood as formulation and articulation of vision and challenging goals and motivating followers to work beyond their self-interest to achieve common goals (Dionne, et al., 2004; Bass and Riggio, 2006). In this dimension, leaders act as role models who are highly admired, respected, and trusted by their followers (Bass \& Riggio, 2006). Leaders with great idealized influence are willing to take risks and are consistent rather than arbitrary by 
Befekadu Zeleke and Belayneh Kifle

demonstrating high standards of ethical and moral conduct (Bass and Riggio, 2006).

Inspirational motivation is described in many pieces of literature as leaders' ability to foster strong team spirit as a means of leading team members towards achieving desired goals (Bass and Riggio, 2006; Antonakis, et al., 2003). Leaders with inspirational motivation foster strong team spirit as a means for leading team members towards achieving desired goals (Bass \& Riggio, 2006).

Intellectual stimulation is the leaders' ability to support followers for being creative and innovative (Bass and Riggio, 2006; Nicholason, 2007). Intellectual stimulation is concerned with the role of leaders in stimulating innovation and creativity in their followers by questioning assumptions and approaching old situations in new ways (Bass \& Riggio, 2006; Nicholason, 2007). They always encourage their followers to try new approaches or methods to solve old problems.

Individualized consideration refers to leaders paying special attention to each follower's need for achievement and growth by acting as a coach or mentor (Bass \& Riggio, 2006; Nicholason, 2007). Transformational leaders create a suitable and supportive environment in which individual differences and needs are considered and the thoughts of the followers are valued (Tourish and Pinnington, 2002). Individual differences are recognized and assignments are delegated to followers to provide learning opportunities (Bass and Avolio, 1991).

\section{Transactional leadership}

Transactional leaders are those who lead through social exchange. As Burns (1978) notes, politicians, for example, led by exchanging one thing for another: jobs for votes, or subsidies for a campaign contribution. Tickle (2004) described transactional leadership as a performance-based system where followers are rewarded or penalized based on work performance. Transactional leaders engage followers by offering rewards in exchange for the achievement of desired goals (Burns, 1978). Bass and Avolio (1995) proposed that transactional leadership consists of three dimensions, namely contingent rewards, management by exception (active), and management by exception (passive).

Contingent reward refers to an exchange process among leaders and followers in which effort by followers is exchanged for specified rewards. With this kind of leadership, the leader tries to obtain agreement from followers on what must be done and what the payoffs will be for the people doing it (Northouse, 2016). This type of leadership refers to leaders clarifying the work that must be achieved and use rewards in exchange for good performance (Antonakis, 2003). 
Management-by-exception refers to leadership that involves corrective criticism, negative feedback, and negative reinforcement. This leadership takes two forms: active and passive. A leader using the active form of management-byexception watches followers closely for mistakes or rule violations and then takes corrective action. On the other hand, a leader using the passive form intervenes only after standards have not been met or problems have arisen (Northouse, 2016).

\section{Laissez-faire leadership}

Laissez-Faire leadership is a passive kind of leadership style. It represents a nontransactional kind of leadership style in which the necessary decisions are not made, actions are delayed, leadership responsibilities are ignored, and authority is not exercised. A leader displaying this form of non-leadership is perceived as not caring at all about others' issues. Laissez-faire leadership is a leadership style in which the leader never intervenes in the administrative processes and gives limitless freedom to the followers (Bass \& Steidlmeier, 1999). Further studies on the style pointed out that style is the most effective in cases where followers are mature and highly motivated (Zervas \& Lassiter, 2007).

\section{Employees' perception of change}

Perception is the process by which an employee organizes and interprets his/her impressions to give meaning to his/her environment and thus, it influences significantly his/her workplace behavior (Langton \& Robbins, 2006). The evidence suggests that what individuals perceive about their work situation influences their attitudes and behavior during organizational change. Thus, employee perceptions will lead to either resistance or acceptance of the change.

To be successful, change leaders should execute a process to influence the beliefs of the change recipient and monitor those beliefs as a way of assessing progress. The five beliefs in determining the reactions of change recipients to organizational transformation are discrepancy, appropriateness, efficiency, principal support, and valence, and how each is related to employees' perception of change are discussed below.

Discrepancy: research by numerous organizational scientists (Rudolph \& DePalma, 2006; Rafferty \& Griffin, 2006) supports the argument that employees must believe a need for change exists. Otherwise, the motive for a change may be perceived as arbitrary. Change recipients' beliefs about discrepancy can be influenced by what Bies (1987) labeled as social accounts, that is, the information provided by change agents to explain why an organizational change is needed. 
Befekadu Zeleke and Belayneh Kifle

Appropriateness: employees' perceived appropriateness of change is very critical for avoiding individual resistance during organizational changes (Armenakis \& Harris, 2002). Leadership should always provide information on why the proposed change initiative is the correct one by noting what the initiative is intended to correct or improve. Further, employees must believe they have the knowledge, skills, and ability to successfully implement the proposed change. Bartunek et al. (2006) have found that when an organizational change is perceived as being implemented, after careful deliberation and planning, change recipients expressed less uncertainty.

Efficacy: refers to the perceived capability to implement the change initiative. Research demonstrated that individuals commonly avoid activities that they believe exceed their coping capabilities. In contrast, individuals will undertake and perform those that they judge themselves to be capable of. Thus, employees must believe they are capable of executing the new behaviors required by the change initiative. Otherwise, the outcome of a change initiative may be less than the expected (McGuire \& Hutchins, 2006).

Principal support: describes the support from change agents. A common phrase associated with this support is walking the talk. Simons (2002) labeled this as behavioral integrity, that is, alignment or misalignment of words and deeds. Leaders act as agents of the organization who have responsibility for leading and appraising employees' performance (Achiles et al. 2007).

Valence: refers to the attractiveness associated with the perceived outcome of the change. This component recognizes the importance of change agents addressing the personal needs of change recipients. Personal gains and losses (i.e., intrinsic valence) from the shared governance initiative are relevant to the change recipients (Bartunek, and Herold, 2006).

\section{Job satisfaction}

Job satisfaction is a positive emotional response from the assessment of a job or specific aspects of a job. Job satisfaction is influenced by factors such as the working condition; work itself, supervision, policy, and administration, advancement, compensation, interpersonal relationships, recognition, and empowerment. Ellickson (2002) suggests that irrespective of the approaches used to study job satisfaction, most studies identified at least two general categories of variables associated with job satisfaction, namely the work environment and factors related to the work itself, and the personal characteristics of the individual. 
Although the literature indicates plenty of job satisfaction theories, Herzberg's two factor theory is probably the most often cited point of view. According to this theory, the five factors stand out as forces of strong job satisfaction, which he called Motivators. Conversely, the eleven factors represent forces of strong job dissatisfaction, which he called Hygiene factors. Herzberg found out that the existence of the motivators tended to affect employee's attitudes in a positive direction. However, a reduction of these same factors does not result in job dissatisfaction. On the other hand, an improvement in one or more of the eleven hygiene factors tended to reduce employee dissatisfaction, but this change does not ensure employee satisfaction (Herzberg, 1976). Hirschfield (2000) further specified that intrinsic job satisfaction refers to how people feel about the nature of the job tasks themselves, whereas extrinsic job satisfaction refers to how people feel about aspects of the work situation that are external to the job tasks or work itself (Shim, et.al., 2002). Poor working conditions, inefficient work organization, inadequate staffing, and managerial practices affect staff turnover and perceptions of the organization and work (Eaton, 2000). Therefore, good working condition is a key factor for workers to develop a value, improve job performance and increase staff retention in an organization.

\section{The relationship between leadership style, job satisfaction, and organizational change}

Many studies have been conducted to examine the relationship between leadership style and job satisfaction. The transformational leadership style is highly effective in enhancing job satisfaction (Lok \& Crawford, 2004). Research also indicates that transformational leadership improves employees' perception and commitment towards the organization (Ojokuku, et al., 2012). A study by Lok and Crawford (2004) confirmed that both transactional and transformational leadership styles affect employee satisfaction. A study by Saleem (2015) confirmed that transformational leadership had a moderately strong positive association with job satisfaction but a weak and negative association between transactional leadership and job satisfaction. According to Epitropaki and Martin (2005b), employees prefer the inspiration and consideration aspects of transformational leadership while they are in favor of the contingent rewards aspect of transactional leadership. Still, some studies found that leadership styles positively affect employees' job satisfaction (Jansen, et al., 2009).

Different studies further indicate that leadership behavior influences followers' reactions to organizational change (Skakon et al., 2010). According to a study by Oreg et al. (2011), positive perceptions towards change are produced if 
Befekadu Zeleke and Belayneh Kifle

leadership changes competency; has a participative, informative approach, ; and is perceived as fair. Leaders are thus important change agents, facilitating the success of organizational change and influencing the degree to which followers embrace change (Armenakis et al., 2007). Herold et al. (2008) further found that change leadership is positively related to followers' change commitment. Similarly, Aarons (2006) found that having a positively perceived local opinion leader to introduce and guide change may facilitate receptivity to change. A study by Kavanagh and Ashkanasy (2006) also found that the change leadership strategy determined followers' acceptance or rejection of change.

Many organizational changes occur based on dealing with changes in the responsibilities of workers, their tasks, and the re-structuring of workplaces. Therefore, job satisfaction is strongly related to the fact that the potential to affect a wide range of behaviors in organizations and contribute to employees' levels of wellbeing (George \& Jones, 2008). Organizational change and reorganizations may influence job and organizational characteristics and, as a result, job satisfaction.

In short, leadership is about influencing others, and the behavior of a leader while influencing followers is his/her leadership style which affects the well-being of followers. The above discussions indicated that leadership style is related to employees' reactions to organizational change. And employees' reactions to change are further related to their job satisfaction and commitment to the implementation of organizational change. Thus, understanding how leadership style is related to employees' reactions to change and their job satisfaction during the time of organizational change through research will help organizations achieve their visions for change which this study tries to explore at the Ethiopian Electric Utility.

\section{Methodology}

\section{The research setting}

The Ethiopian Electric Light and Power Authority (EELPA) was established in 1956, after having undergone restructuring it had been reorganized as Ethiopian Electric Power Corporation (EEPCo) and is named in 1997 for an indefinite duration by regulation No. 18/1997. To improve its service and to meet the energy demand of the country the corporation has made demarcation and was restructured into two big corporations: Ethiopian Electric Utility (EEU) and Ethiopian Electric Power (EEP). The EEP is formed by Council of Minister's Regulation No. 302/2013 dated 27th of December, 2013 with a mandate of designing and developing electric generation, transmission, and substations and all operational 
and maintenance tasks more than $66 \mathrm{KVA}$. And EEU is established by Councils of Minister's Regulation No. 303/2013 dated 27th of December 2013 with the responsibility of administering electric power distribution networks, purchase bulk electric power, and sell energy to customers. Problems of service delivery, delay in rehabilitation of old lines, lengthy institutional reforms are some of the problems observed in the power sector that deserves proper attention. To minimize these problems EEU has conducted several reforms and institutional changes in the past. Yet, no study has been conducted to examine employees' reactions to these changes and their job satisfaction with these reforms, and the leadership style of their leaders during the time of the reform, which this study tries to fill in.

\section{Research design}

A correlation research design was used to achieve the objectives of the study as it is more appropriate to show the relationships between the variables of the study.

\section{Sampling techniques}

The sample respondents for the study were drawn from the total 1365 population whose educational qualifications were diploma and above, who were working at Addis Ababa in the Head Quarter, and West and South Addis Ababa Regions as they could represent the total population. The sample size is determined using a formula developed by Mugenda (2003). By using a 95\% confidence level and sampling errors of 5\% probability technique, 310 respondents were selected using stratified random and simple random sampling techniques.

$$
\mathrm{n}=\mathrm{N} \div\left(1+\left(\mathrm{N} * \mathrm{e}^{2}\right)\right.
$$

Where: $\mathrm{N}=$ population size

$\mathrm{e}=$ Tolerance at desired level of confidence, take 0.05 at $95 \%$ confidence

level

$\mathrm{n}=$ sample size.

Therefore, the sample size is $\mathrm{n}=\frac{1365}{\left(1+\left(1,365^{*} 0.05^{*} 0.05\right)\right)} \mathrm{n}=310$

The 310 respondents were selected from the three offices (Head Quarter, West Addis Ababa Region, and South Addis Ababa Region) using proportionate stratified random sampling. Proportionate stratified random sampling is widely used to guarantee the equal representation of the population in the samples. 
Befekadu Zeleke and Belayneh Kifle

\section{Measurements}

The data was collected using three standardized questionnaires merged into one with additional biodata of respondents: The Multifactor Factor Leadership Questionnaire (MLQ), the Job Satisfaction Survey (JSS), and the Organizational Change Recipients Beliefs Scale (OCRBS).

\section{Multifactor leadership questionnaire (MLQ Form 5X)}

The revised Multifactor Leadership Questionnaire (MLQ) 5X short items developed by Bass and Avolio (1995) was used to gather primary data from both the leaders and the non-leader staff at Ethiopian Electric Utility on the three leadership styles. However, only thirty-six items linked to nine subscales relating to transformational, transactional, or Laissez-faire leadership styles were used. The items were rated using a five-point scale by respondents. The numerical scale is $0=$ not at all, $1=$ once in a while, $2=$ =sometimes, $3=$ fairly often, and $4=$ frequently, if not always. The reliability of MLQ is tested many times in different places and was reported above 0.80 (Bass \& Riggio, 2006). In addition, the MLQ has been revised many times, strengthening its validity and reliability (Bass \& Avolio, 2000). Moreover, the reliability of the instrument was computed in this study and found to range from (r) 0.71 to 0.89 for the three leadership styles.

\section{The organizational change recipient's belief scale (OCRBS)}

This standardized questionnaire is developed by Armenakis, et al. (2007) for assessing the beliefs of members on organizational change and used to measure the process of organizational change efforts of members at the Ethiopian Electric Utility. Moreover, the beliefs identified in terms of discrepancy, appropriateness, efficacy, leaders' support, and valence helped to examine employees' perceptions toward organizational change. The instrument contains 24 items and rated using a five-point Likert scale: $0=$ Not at all, $1=$ To a slight extent, $2=$ To a moderate extent, $3=$ To a great extent, $4=$ To a very great extent. The reliability coefficient of change measured by the developers of the questionnaire ranged from 0.86 to 0.97 . The reliability of the instrument was also computed in this study and ranges from 0.78 to 0.91 for the five dimensions on employees' perceptions.

\section{Job satisfaction survey (JSS)}

The job satisfaction survey (JSS) was developed by Spector (1985) containing 36 items. The questionnaire assesses two aspects of employees' job satisfaction i.e. Intrinsic and Extrinsic Job Satisfaction. The items were rated using six points scale from 1=Disagree very much, $2=$ Disagree moderately, $3=$ Disagree slightly, $4=$ Agree slightly 5=Agree moderately, $6=$ Agree very much. Among the 36 items, 19 
are stated negatively. The reliability of JSS is mentioned by Spector (in Hamidifar, 2010) to be a Cronbach alpha ranging from 0.60 to 0.82 while the current reliability in this study ranges from 0.68 to 0.79 for all items.

\section{Variables of the study}

Leadership styles of transformational, transactional, and laissez-faire leadership styles, the organizational change perception through the dimensions of a discrepancy, appropriateness, principal support, efficacy and valance, and job satisfaction through its dimensions: intrinsic and extrinsic were the variables considered in this study. While leadership styles were treated as independent variables, organizational change perception and employees' job satisfaction were considered as the dependent variables in the study.

\section{Data analysis}

An independent sample t-test was used to determine if a significant difference exists between the means of two independent samples (leaders and employees). Independent samples are randomly formed without any type of matching; the members of one sample are not related to members of the other sample in any systematic way other than that they are selected from the same population (Bhattacherjee, 2012). MANOVA was used to identify the statistically significant differences and similarities, and the degree of agreement and disagreement among leaders and non-leaders on their mean ratings and as there are two dependent variables. An alpha level of 0.05 was used as the level of significance in this study. Finally, the strength of correlation between the three variables (leadership styles, change perception, and job satisfaction) was conducted using Pearson Correlation Coefficient. Regression analysis was used to investigate the relationship between an independent variable and two or more dependent variables due to its welldeveloped underlying statistical theory (Hair et al., 2006; Montgomery et al., 2001). As stated in Cohen-Swerdlik (2009), regression analysis takes into account the inter-correlations among all variables involved. Thus, linear regression analysis was used to examine the relationships between leadership styles and change perceptions, and employees' job satisfaction.

\section{Results and discussions \\ Characteristics of respondents}

Data for the study was gathered from a total of 310 respondents (40 leaders and 270 non-leaders). The majority (nearly $55 \%$ ) of the study participants were $\mathrm{BA} / \mathrm{BSC}$ graduates while very few of them had MA/MSC qualifications. Out of 
Befekadu Zeleke and Belayneh Kifle

the total respondents, 187 (69\%) were males and 83 (31\%) were female respondents. Their service years range from six to twenty-five years and above.

Leadership style at EEU as perceived by respondents

Table 1: Descriptive Statistics of Leadership Styles as perceived by respondents

\begin{tabular}{lccccc}
\hline Dimensions & N & Min. & Max. & Mean & $\begin{array}{r}\text { Std. } \\
\text { Deviation }\end{array}$ \\
\hline Transformational Leadership & 310 & 0.65 & 3.85 & 2.37 & 0.60 \\
Idealized Influence (Behavior) & 310 & 0.00 & 4.00 & 2.37 & 0.76 \\
Idealized Influence (Attributed) & 310 & 0.00 & 4.00 & 2.49 & 0.71 \\
Inspirational Motivation & 310 & 0.25 & 4.00 & 2.33 & 0.81 \\
Intellectual Stimulation & 310 & 0.50 & 3.75 & 2.24 & 0.77 \\
Individual Consideration & 310 & 0.25 & 4.00 & 2.44 & 0.71 \\
\hline $\begin{array}{l}\text { Transactional Leadership } \\
\text { Contingent Reward }\end{array}$ & 310 & 0.75 & 3.58 & 2.06 & 0.47 \\
$\begin{array}{l}\text { Management by Exception } \\
\text { (Active) }\end{array}$ & 310 & 0.00 & 4.00 & 2.44 & 0.70 \\
$\begin{array}{l}\text { Management by Exception } \\
\text { (Passive) }\end{array}$ & 310 & 0.25 & 3.75 & 1.96 & 0.64 \\
\hline Laissez-fairs & 310 & 0.00 & 4.00 & 1.77 & 0.76 \\
\hline
\end{tabular}

As one could infer from data in the table, the mean score of transformational leadership style was $(\mathrm{M}=2.37, \mathrm{SD}=.60)$, transactional leadership style has a mean rating of (M: 2.067; SD, 0.47); and the laissez-faire leadership style with the least preferred leadership style and mean score of $(\mathrm{M}=1.67, \mathrm{SD}=.82)$. On the other hand, when one looks at the mean score of the sub variables of transformational leadership styles, idealized influence (Attribute), $(\mathrm{M}=2.49, \mathrm{SD}=.71)$, was the highest in this category followed by individual consideration and idealized influence (behavior) with a mean score of $(\mathrm{M}=2.44,2.37)$, and $(\mathrm{SD}=0.71,0.76)$ respectively. The mean score for transactional leadership style dimensions were also computed and the following mean and standard deviations were recorded (contingent reward $(\mathrm{M}=2.44, \mathrm{SD}=0.70)$, management by exception-active $(\mathrm{M}=1.96, \mathrm{SD}=0.64)$, management by exception-passive, $(\mathrm{M}=1.77, \mathrm{SD}=0.76)$ and laissez-faire leadership style, $(\mathrm{M}=1.67, \mathrm{SD}=0.82)$. From this, one could see that respondents' perceptions of contingent reward $(\mathrm{M}=2.44, \mathrm{SD}=0.70)$, under transactional leadership style was the highest in this category.

Thus, the dominant transformational leadership style component was idealized influence and the dominant transactional leadership style component was contingent reward. Idealized influence is understood as formulation and 
articulation of vision and challenging goals and motivating followers to work beyond their self-interest in order to achieve common goals (Dionne, et al., 2004; Bass \& Riggio, 2006). This component tells us the behavior of a leader who acts a role model for followers. According to Bass and Riggio (2006), leaders with great idealized influence are willing to take risks and are consistent rather than arbitrary by demonstrating high standards of ethical and moral conduct.

However, Bass and Avolio (1999) suggest that the ideal mean score required for good leadership is greater than 3 for all the dimensions of transformational leadership style, 2.00 for transactional, and nearly 1.00 for laissez-faire (Antonakis et al., 2003). From this one could infer that leaders at the Ethiopian Electric Utility are slightly close to transformational but more of transactional in their leadership style. Having transformational leaders in an organization is particularly essential in today's fast-changing environment where such leaders motivate others to work beyond what is expected from followers (Northouse, 2016). Such leaders pay great attention to the need and interests of those whom they lead. They try to support their followers to reach their fullest potential (Bass, 1997; Northouse, 2013; Bass \& Riggio, 2006).

Bass and Avolio (1999) suggest that for effective leadership the mean score for contingent reward should be greater than 2. The suggested mean score for Management by Exception (Active) was less than 1.5 and for management by exception (passive) was less than 1 (Antonakis et al., 2003). Besides, it is indicated that contingent reward is transformational when the reward can be psychological such as praise (Bass and Riggio, 2006). That means, when leaders frequently use the psychological rewards, subordinates become motivated and do more. Leaders that use management by exception give negative feedback, corrective criticism, and negative reinforcement (Northouse, 2013). Therefore, from the above respondents' data, the mean score of leadership styles (idealized influence was the highest and the mean score of laissez-faire leadership style was the least $(2.49$, and 1.67) respectively in their category and yet Avolio et.al. (1999) suggests that for a leader to be effective, the mean score of his/her laissez-faire leadership must be less than 1. This indicates that the leaders in the organization under study uses a laissez-faire style of leadership more than the expected or ideal mean score which requires further investigation. 
Befekadu Zeleke and Belayneh Kifle

Table 2: Independent t-Test

\begin{tabular}{|c|c|c|c|c|c|c|c|c|c|c|}
\hline \multicolumn{2}{|c|}{ Variables } & \multicolumn{2}{|c|}{$\begin{array}{l}\text { Levine's Test } \\
\text { for Equality of } \\
\text { Variances }\end{array}$} & \multicolumn{7}{|c|}{ t-test for Equality of Means } \\
\hline & & \multirow[t]{2}{*}{$\mathbf{F}$} & \multirow[t]{2}{*}{ Sig. } & \multirow[t]{2}{*}{$\mathbf{T}$} & \multirow[t]{2}{*}{ df } & \multirow[t]{2}{*}{$\begin{array}{l}\text { Sig. } \\
(2 \\
\text { tailed })\end{array}$} & \multirow[t]{2}{*}{$\begin{array}{c}\text { Mean } \\
\text { Differ } \\
\text { ence }\end{array}$} & \multirow[t]{2}{*}{$\begin{array}{l}\text { Std. } \\
\text { Error } \\
\text { Diff }\end{array}$} & \multicolumn{2}{|c|}{$\begin{array}{c}95 \% \\
\text { Confidence } \\
\text { Interval of the } \\
\text { Difference } \\
\end{array}$} \\
\hline & & & & & & & & & Low & Up \\
\hline \multirow[t]{2}{*}{$\begin{array}{l}\text { Transformational } \\
\text { Leadership }\end{array}$} & $\begin{array}{l}\text { Equal variances } \\
\text { assumed }\end{array}$ & .919 & .339 & -6.083 & 308 & .000 & -.593 & .098 & -.785 & -.401 \\
\hline & $\begin{array}{l}\text { Equal variances not } \\
\text { assumed }\end{array}$ & - & - & -6.638 & 54.710 & .000 & -.593 & .089 & -.773 & -.414 \\
\hline \multirow[t]{2}{*}{$\begin{array}{l}\text { Transactional } \\
\text { Leadership }\end{array}$} & $\begin{array}{l}\text { Equal variances } \\
\text { assumed }\end{array}$ & 2.274 & .133 & -.442 & 308 & .659 & -.033 & .075 & -.181 & .114 \\
\hline & $\begin{array}{l}\text { Equal variances not } \\
\text { assumed }\end{array}$ & & & -.528 & 59.450 & .599 & -.033 & .063 & -.159 & .092 \\
\hline \multirow[t]{2}{*}{ Laissez-fairs } & $\begin{array}{l}\text { Equal variances } \\
\text { assumed }\end{array}$ & 13.747 & .000 & 3.549 & 308 & .000 & .484 & .136 & .216 & .753 \\
\hline & $\begin{array}{l}\text { Equal variances not } \\
\text { assumed }\end{array}$ & - & - & 2.910 & 45.985 & .006 & .484 & .166 & .149 & .819 \\
\hline
\end{tabular}

According to data in table 2, comparisons were made between the average scores of leaders and non-leaders on leadership styles. The data showed that there were statistically significant differences in the scores of transformational and laissez-faire leadership styles $(\mathrm{P}<0.05)$. The magnitude of the differences between the leaders and the non-leaders on transactional leadership style was not significant $(\mathrm{P}>0.05)$. This indicates that the two groups of respondents have similar perceptions while rating transactional leadership than the other two types of leadership styles.

\section{Respondents' perception towards change at the Ethiopian Electric Utility}

The following table presents responses obtained from sample respondents of Ethiopian Electric Utility. 
Table 3: An Independent t-test Result of Respondents' Perceptions on Organizational Change

\begin{tabular}{llllllll}
\hline No & Items & Respondents & N & Mean & SD & F & Sig \\
\hline 1 & Discrepancy & Leaders & 40 & 3.18 & 0.531 & \multirow{2}{*}{.000} \\
& & Employees & 270 & 2.53 & 0.822 & & \\
\hline \multirow{2}{*}{2} & \multirow{2}{*}{ Appropriateness } & Leaders & 40 & 2.71 & 0.373 & & .000 \\
& & Employees & 270 & 2.18 & 0.721 & 20.46 & \\
\hline 3 & Efficacy & Leaders & 40 & 3.03 & 0.613 & & .000 \\
& & Non leaders & 270 & 2.38 & 0.837 & 21.77 & \\
\hline 4 & Principal Support & Leaders & 40 & 3.34 & 0.572 & & .000 \\
& & Employees & 270 & 2.49 & 0.771 & 45.23 & \\
\hline 5 & Valence & Leaders & 40 & 3.24 & 0.647 & 35.87 & .000 \\
& & Employees & 270 & 2.43 & 0.821 & & \\
\hline
\end{tabular}

Data in table 3 indicated that discrepancy was rated 3.18 for leaders displaying that leaders need to change the way they did something in their organization to a moderate extent while the computed mean value of 2.53 for nonleaders confirmed that they need a change in a lesser extent. The t-value ( $\mathrm{sig}=$ $.000, \mathrm{P}<0.05$ ) shows that there was a statistically significant difference between the two groups of respondents. The data entails that information provided by change agents to explain why an organizational change is needed might have been paid little heed in the organization. The computed mean values 2.71 and 2.18 for appropriateness for the two groups confirmed a moderate. The t-test result $(\mathrm{P}<$ 0.05 ) displays that there was a statistically significant difference between the two groups of respondents in their perceptions. From this, one can realize that the change effort introduced by the organization and the leadership role toward the change effort was not equally perceived among respondents. The computed mean values for efficacy 3.03 and 2.38 for leaders and non-leaders respectively confirm that while leaders agreed to a moderate extent the non-leaders agreed to a slight extent for efficacy. Moreover, the t-test result $(\mathrm{P}<0.05)$ proved that there was a statistically significant difference in perceptions among the two groups of respondents. The computed mean for principal support was 3.34 and 2.49 for leaders and non-leaders respectively confirming that principal support from leaders in the organization was provided to a great extent as perceived by leaders but it was perceived as moderate for non-leaders. The t-test result $(\mathrm{P}<0.05)$ indicates that there was a statistically significant difference among the two groups of respondents. The calculated mean values for valence were 3.24 to 2.43 for leaders 
Befekadu Zeleke and Belayneh Kifle

and non-leaders respectively confirming a moderate extent for leaders but to a slight extent for non-leaders. The t-test result $(\mathrm{P}<0.05)$ shows that there was a statistically significant mean difference among the groups. As one could infer from the above discussions, all of the five dimensions on change perceptions were better rated by leaders than the subordinates. This might further indicate that change at the organization under study was perceived positively by the leaders than by their subordinates.

Relationship between Leadership Styles and Organizational Change

Table 4: Correlation Analysis of Leadership Styles and Organizational Change, $\mathrm{N}=310$

\begin{tabular}{|c|c|c|c|c|c|}
\hline Variables & $\begin{array}{l}\text { Pearson } \\
\text { Correlation and } \\
\text { Significant level } \\
\end{array}$ & Change & $\begin{array}{l}\text { Transformation } \\
\text { al Leadership }\end{array}$ & $\begin{array}{c}\text { Transaction } \\
\text { al } \\
\text { Leadership }\end{array}$ & Laissez-fairs \\
\hline \multirow[t]{2}{*}{ Change } & $\begin{array}{l}\text { Pearson } \\
\text { Correlation }\end{array}$ & 1 & $.247^{* * *}$ & .016 & $.174^{* *}$ \\
\hline & Sig. (2-tailed) & & .000 & .775 & .002 \\
\hline \multirow{2}{*}{$\begin{array}{l}\text { Transformatio } \\
\text { nal Leadership }\end{array}$} & $\begin{array}{l}\text { Pearson } \\
\text { Correlation }\end{array}$ & $.247^{* *}$ & 1 & $.120^{*}$ & $.173^{* *}$ \\
\hline & Sig. (2-tailed) & .000 & & .035 & .002 \\
\hline \multirow{2}{*}{$\begin{array}{l}\text { Transactional } \\
\text { Leadership }\end{array}$} & $\begin{array}{l}\text { Pearson } \\
\text { Correlation }\end{array}$ & .016 & $.120^{*}$ & 1 & $.351^{* * *}$ \\
\hline & Sig. (2-tailed) & .775 & .035 & & .000 \\
\hline Laissez-fairs & $\begin{array}{l}\text { Pearson } \\
\text { Correlation } \\
\text { Sig. (2-tailed) }\end{array}$ & $\begin{array}{l}.174^{* *} \\
.002\end{array}$ & $\begin{array}{l}.173^{* * *} \\
.002\end{array}$ & $\begin{array}{l}.351^{* * *} \\
.000\end{array}$ & 1 \\
\hline
\end{tabular}

As can be seen from the data in table 4, there were statistically significant and positive but weak and very weak correlations between the mean scores of transformational $(\mathrm{r}=0.247)$, and laissez-faire leadership style $(\mathrm{r}=0.174)$ with organizational change respectively $(\mathrm{P}<0.05)$. Besides, the data revealed that there was a positive and non-significant correlation between transactional leadership style and organizational change $(\mathrm{P}>0.05, \mathrm{r}=0.016)$. 


\section{Linear regression analysis of leadership styles and change perceptions}

As it is indicated in the table below, stepwise regression was computed using leadership styles as a predictor and change perception as a dependent variable.

Table 5: Linear Regression Analysis, Model Summary

\begin{tabular}{|c|c|c|c|c|}
\hline \multicolumn{5}{|c|}{ Standardized } \\
\hline \multicolumn{2}{|r|}{ Model } & Coefficients & $\mathbf{t}$ & Sig. \\
\hline \multirow{4}{*}{1} & (Constant) & & 13.953 & .000 \\
\hline & Transformational Leadership & .228 & 4.086 & .000 \\
\hline & Transactional Leadership & .067 & 1.135 & .257 \\
\hline & Laissez-fairs & .158 & 2.674 & .008 \\
\hline
\end{tabular}

a. Dependent Variable: Organizational Change

As it could be seen from the data in the table, the transformational leadership style was the strongest predictor $(\beta=0.228, \mathrm{P}<0.05)$ followed by laissezfaire leadership style $(\beta=0.158, \mathrm{P}<0.05)$ on the organizational change perceptions. This result was similar to Morales, et.al. (2012) research that showed transformational leadership influences organizational performance positively through organizational learning and innovation as they are also related to change in an organization. The researchers concluded that transformational leadership is needed for organizations to improve their performance in changing real-life business environments.

Relationship between leadership styles and job satisfaction (intrinsic and extrinsic)

A Pearson product-moment correlation was also conducted to see the relationship between transformational, transactional, and laissez-faire leadership styles and intrinsic and extrinsic dimensions of job satisfaction of non-leaders' as shown in the table below. 
Befekadu Zeleke and Belayneh Kifle

Table 6: Correlation Analysis of Leadership Styles and Job Satisfaction (Intrinsic and Extrinsic)

\begin{tabular}{|c|c|c|c|c|c|c|}
\hline \multicolumn{2}{|c|}{ Variables } & $\begin{array}{c}\text { Transformational } \\
\text { Leadership }\end{array}$ & $\begin{array}{l}\text { Transactional } \\
\text { Leadership }\end{array}$ & $\begin{array}{l}\text { Laissez- } \\
\text { Faire }\end{array}$ & Intrinsic & Extrinsic \\
\hline \multirow{2}{*}{$\begin{array}{l}\text { Transformational } \\
\text { Leadership }\end{array}$} & $\begin{array}{l}\text { Pearson } \\
\text { Correlation }\end{array}$ & 1 & $.120 *$ & $.173 * *$ & .001 & .054 \\
\hline & $\begin{array}{l}\text { Sig. }(2- \\
\text { tailed })\end{array}$ & & .035 & .002 & .985 & .376 \\
\hline \multirow{2}{*}{$\begin{array}{l}\text { Transactional } \\
\text { Leadership }\end{array}$} & $\begin{array}{l}\text { Pearson } \\
\text { Correlation }\end{array}$ & $.120 *$ & 1 & $.351 * *$ & $.331 * *$ & $.404 * *$ \\
\hline & $\begin{array}{l}\text { Sig. (2- } \\
\text { tailed) }\end{array}$ & .035 & & .000 & .000 & .000 \\
\hline \multirow{2}{*}{ Laissez-Faire } & $\begin{array}{l}\text { Pearson } \\
\text { Correlation }\end{array}$ & $.173 * *$ & $.351 * *$ & 1 & $.128 *$ & $.184 * *$ \\
\hline & $\begin{array}{l}\text { Sig. }(2- \\
\text { tailed) }\end{array}$ & .002 & .000 & & .036 & .002 \\
\hline \multirow{2}{*}{ Intrinsic } & $\begin{array}{l}\text { Pearson } \\
\text { Correlation }\end{array}$ & .001 & $.331 * *$ & $.128 *$ & 1 & $.803 * *$ \\
\hline & $\begin{array}{l}\text { Sig. }(2- \\
\text { tailed) }\end{array}$ & .985 & .000 & .036 & & .000 \\
\hline \multirow[t]{2}{*}{ Extrinsic } & $\begin{array}{l}\text { Pearson } \\
\text { Correlation }\end{array}$ & .054 & $.404 * *$ & $.184 * *$ & $.803 * *$ & 1 \\
\hline & $\begin{array}{l}\text { Sig. (2- } \\
\text { tailed) }\end{array}$ & .376 & .000 & .002 & .000 & \\
\hline
\end{tabular}

**. Correlation is significant at the 0.01 level (2-tailed). *. Correlation is significant at the 0.05 level (2tailed).

As it is shown in the data above, there was a positive correlation between transformational leadership style and intrinsic and extrinsic dimensions of job satisfaction, but in both cases, the correlation was not statistically significant $(\mathrm{r}=0.01, \mathrm{P}=0.296)$ and $(\mathrm{r}=0.54, \mathrm{P}=0.376)$ respectively. In addition, there was a positive, and significant correlation between the transactional leadership style with intrinsic job satisfaction $(\mathrm{r}=331)$, and extrinsic job satisfaction $(\mathrm{r}=0.404)$, the degree of association of that of transactional with intrinsic was weak but was moderate $(\mathrm{P}<0.05)$ with extrinsic job satisfaction. There was also a positive and significant correlation between laissez-faire leadership style and intrinsic job satisfaction $(\mathrm{r}=0.128, \mathrm{P}<0.05)$, and $(\mathrm{r}=0.184 \quad \mathrm{P}<0.05)$ with extrinsic job satisfaction. However, the degree of association between laissez-faire leadership style and job satisfaction (intrinsic and extrinsic) was very weak. Therefore, 
employees at the Ethiopian Electric Utility who are satisfied with the transactional leadership style are more satisfied than others by their leaders.

\section{Regression Analysis of Leadership Styles and Job Satisfaction}

A linear regression analysis was also computed using leadership style characteristics as a predicator and employee's job satisfaction (Intrinsic and Extrinsic) as a dependent variable.

Table 7: Linear Regression Analysis Model Summary

\begin{tabular}{|c|c|c|c|c|c|c|c|c|}
\hline \multirow[t]{2}{*}{ Model } & \multicolumn{2}{|c|}{$\begin{array}{c}\text { Constant } \\
\text { (Predicator) }\end{array}$} & \multicolumn{2}{|c|}{$\begin{array}{c}\text { Transformational } \\
\text { Leadership }\end{array}$} & \multicolumn{2}{|c|}{$\begin{array}{l}\text { Transactional } \\
\text { Leadership }\end{array}$} & \multicolumn{2}{|c|}{ Laissez-Faire } \\
\hline & Intrinsic & Extrinsic & Intrinsic & Extrinsic & Intrinsic & Extrinsic & Intrinsic & Extrinsic \\
\hline $\begin{array}{l}\text { Standardized } \\
\text { Coefficients }(\beta)\end{array}$ & - & 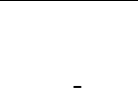 & .024 & لي 092 & 340 & 399 & -016 & 027 \\
\hline $\mathrm{t}$ & 11.971 & 13.369 & .402 & 1.621 & 5.296 & 6.436 & -.249 & 430 \\
\hline Sig & 0.000 & 0.000 & .688 & .106 & 0.000 & 0.000 & .804 & .668 \\
\hline
\end{tabular}

As data in the table reveals, transactional leadership style was the strongest predictor on intrinsic $(\beta=0.34, \mathrm{P}<0.05)$ and extrinsic $(\beta=0.40, \mathrm{P}<0.05)$ job satisfaction of the non-leader respondents. In this data, one can learn that employees report better job satisfaction with transactional leadership style than transformational and laissez-faire leadership styles. Considerable work conducted to understand the assumption of transactional leadership has verified that transactional leaders use rewards, praises, and promises that would satisfy followers' immediate needs (Northouse, 2010). Such relationship is considered as exchange relationship where each of them (leaders and follower) enters the transaction because of the expectation to fulfill self-interests (Bogler, 2001) and the results from this study also confirms this fact.

The relationship among leadership style, organizational change perception and employees' job satisfaction

A Pearson product-moment correlation was computed to identify the level of relationships among leadership styles, organizational change perception, and employee's job satisfaction. 
Befekadu Zeleke and Belayneh Kifle

Table 8: Correlation analysis of leadership styles, organizational change and employee

\begin{tabular}{|c|c|c|c|c|c|}
\hline $\begin{array}{l}\text { Job Satisfaction } \\
\text { Variables } \\
\end{array}$ & $\begin{array}{c}\text { Transformational } \\
\text { Leadership }\end{array}$ & $\begin{array}{c}\text { Transactional } \\
\text { Leadership }\end{array}$ & $\begin{array}{l}\text { Laissez- } \\
\text { Faire } \\
\end{array}$ & Change & $\begin{array}{c}\text { Job } \\
\text { Satisfaction } \\
\end{array}$ \\
\hline $\begin{array}{l}\text { Transformational } \\
\text { Leadership }\end{array}$ & 1 & & & & \\
\hline $\begin{array}{l}\text { Transactional } \\
\text { Leadership }\end{array}$ & $.120 *$ & 1 & & & \\
\hline Laissez-Faire & $.173^{* *}$ & $.351 * *$ & 1 & & \\
\hline Change & $.247 * *$ & .016 & $.174 * *$ & 1 & \\
\hline Job Satisfaction & .028 & $.387 * *$ & $.164 * *$ & -.069 & 1 \\
\hline
\end{tabular}

As indicated in the data above, there was a statistically significant and positive correlation between transformational leadership style and employees' change perception $(\mathrm{r}=0.247, \mathrm{P}<0.05)$. Furthermore, there was a statistically significant and positive correlation between transactional leadership style with employees' job satisfaction $(\mathrm{r}=0.387, \mathrm{P}<0.05)$, but the correlation was weak. If one critically examines the data on the relationship between laissez-faire leadership style, employees' change perception, and their job satisfaction, one could see a positive and significant correlation between change perceptions and job satisfaction $(\mathrm{r}=0.174, \mathrm{P}<0.05),(\mathrm{r}=0.164, \mathrm{P}<0.05)$ respectively. In addition, there was a negative correlation between organizational change and employees' job satisfaction, and the correlation was not statistically significant $(\mathrm{P}=0.258, \mathrm{r}=-.069)$. 


\section{MANOVA result}

Table 9: Multivariate test among leadership styles, change and employee job satisfaction

Tests of between-Subjects Effects

\begin{tabular}{|c|c|c|c|c|c|c|}
\hline Source & Dependent Variable & $\begin{array}{l}\text { Type III Sum } \\
\text { of Squares }\end{array}$ & df & $\begin{array}{c}\text { Mean } \\
\text { Square }\end{array}$ & $\mathbf{F}$ & Sig. \\
\hline \multirow{2}{*}{ Corrected Model } & Organizational Change & $66.254 \mathrm{a}$ & 2 & .631 & 2.685 & .000 \\
\hline & $\begin{array}{ll}\text { Employee } & \text { Job } \\
\text { Satisfaction } & \end{array}$ & $59.132 b$ & 2 & .563 & 3.834 & .000 \\
\hline \multirow[b]{2}{*}{ Intercept } & Organizational Change & 2325.281 & 1 & 2325.281 & 9896.224 & .000 \\
\hline & $\begin{array}{ll}\text { Employee } & \text { Job } \\
\text { Satisfaction } & \\
\end{array}$ & 1459.090 & 1 & 1459.090 & $\begin{array}{c}9932.26 \\
6 \\
\end{array}$ & .000 \\
\hline \multirow{2}{*}{$\begin{array}{l}\text { Leadership } \\
\text { Styles }\end{array}$} & Organizational Change & 66.254 & 2 & .631 & 2.685 & .000 \\
\hline & $\begin{array}{ll}\text { Employee } & \text { Job } \\
\text { Satisfaction } & \\
\end{array}$ & 59.132 & 2 & .563 & 3.834 & .000 \\
\hline \multirow[b]{2}{*}{ Error } & Organizational Change & 38.535 & 307 & .235 & & \\
\hline & $\begin{array}{ll}\text { Employee } & \text { Job } \\
\text { Satisfaction } & \\
\end{array}$ & 24.092 & 307 & .147 & & \\
\hline \multirow[b]{2}{*}{ Total } & Organizational Change & 3582.445 & 310 & & & \\
\hline & $\begin{array}{ll}\text { Employee } & \text { Job } \\
\text { Satisfaction } & \\
\end{array}$ & 2236.087 & 310 & & & \\
\hline \multirow[b]{2}{*}{ Corrected Total } & Organizational Change & 104.788 & 309 & & & \\
\hline & $\begin{array}{ll}\text { Employee } & \text { Job } \\
\text { Satisfaction } & \\
\end{array}$ & 83.224 & 309 & & & \\
\hline
\end{tabular}

a. R Squared $=.632$ (Adjusted R Squared $=.397)$, b. R Squared $=.711$ (Adjusted $\mathrm{R}$ Squared $=.525$ )

In this study a multivariate analysis of variance MANOVA was conducted to determine if there were differences between the three leadership style groups on a linear combination of the two dependent variables of change perceptions and employees' job satisfaction. Accordingly, a significant difference was found, Wilki's $\lambda=.342, \mathrm{~F}(1,307)=2.685, \mathrm{p}=.000$, multivariate $\square 2=.24$ showing moderate effect size. Examinations for the coefficients for the linear combinations distinguishing the three leadership style groups indicated that both change perceptions and employees' job satisfaction were influenced by the leadership styles, with higher influence on job-satisfaction than change perception. In particular as shown in the table, leadership styles caused significant difference on employee job satisfaction $\mathrm{F}(2,307)=3.834, \mathrm{P}<0.05$, and change perception $\mathrm{F}(2$, $307)=2.685, \mathrm{P}<0.05$. 
Befekadu Zeleke and Belayneh Kifle

\section{Findings and policy implications Findings}

The study examined the relationship between leadership styles, change perceptions, and employees' job satisfaction at the Ethiopian Electric Utility. Based on the results from data the following conclusions were drawn.

This research revealed that employees at the organization under study perceive that their leaders use a slightly transformational leadership style than the other two styles. Moreover, a comparison between leaders' and employees' means ratings indicated statistically significant differences for two of the styles (transformational and laissez-faire) but no significant difference was observed for transactional leadership style between the two groups of respondents.

Change perceptions of respondents further proved that leaders were rated higher in all dimensions of change perception than non-leader respondents. Few differences between respondents were recorded on the appropriateness and efficacy of change perceptions. Therefore, these differences show that the change efforts at the Ethiopian Electric Utility might not be well introduced to all members of the organization.

The correlation results further disclosed that transformational leadership style was positively correlated with change perceptions while transactional leadership style was positively correlated with employees' job satisfaction. In both cases, there were significant differences between transformational leadership with change perceptions and transactional leadership with employees' job satisfaction. This shows that leaders use more of the transformational leadership style so that the change effort will be realized. Similarly, the correlation between transactional leadership style and job satisfaction indicates that employees prefer the style in the implementation of change at the organization. This is because they expect a sort of rewards in a form of pay increase or material incentives during change implementation and thereby increases the level of their job satisfaction. This is something obvious because employees in any organization raise a question of what is in it (change) for me during the implementation of any change. This further implies that although leaders are expected to widely use the transformational leadership style during the time of change, they are also expected to use the transactional leadership style so that employees get satisfied in their job during the time of change.

\section{Policy implications}

In light of the major findings of the study, the following policy implications are forwarded to strengthen the positive aspects of leaders at the Ethiopian Electric 
Utility. According to the growth and transformation plan (2015/16-2019/20), the energy sector is given high emphasis and expected to expand power transmission considering environmental conservation issues; make service delivery reliable, and efficient; as well as transform institutions and accelerate technological transfer and distribution.

The Ethiopian Electric Utility has made an organizational transformation and set its five years strategic plan. One of the strategic plans was developing the human capital capacity, adoption of new technology, and innovation to sustain the growth of the organization. These human resource capabilities will help improve the quality-of-service delivery and enhance the workforce skills and national capacity. To realize this objective, great effort is expected from leaders of the Ethiopian Electric Utility to improve the current status of change perceptions and job satisfaction of their employees through continuous training and orientation programs as well as designing fringe benefit schemes to improve the existing level of job satisfaction.

The change recipient's belief plays a key role in the ultimate success or failure of organizational change initiatives. So, without securing employees' cooperation, changing an organization is impossible. To capture the hearts and minds of employees, change leaders need to communicate the need for change to employees in an adequate manner. Transformational efforts fail due to inadequate communication of vision to the implementers. Hence, leaders at the Ethiopian Electric Utility should make greater efforts to communicate change efforts in the organization to strengthen their leadership quality through regular leadership development programs to realize the intended change in the organization.

Leaders at the Ethiopian Electric Utility should also make special attention to employees' job satisfaction and their commitment to their jobs. The attention area should focus on the employees' job satisfaction and commitment like personal development and training, fair benefits and incentives, continuous support, fair and equitable promotion in the area of professional responsibility. This helps employees increase the level of job satisfaction as well as maximize their level of commitment to achieve the strategic goals of their organization.

The above findings from the Ethiopian Electric Utility indicate that leaders in any public organization embarked on a change in Ethiopia ought to match their leadership style with employees' job satisfaction to achieve the envisioned change in their respective organizations. Hence, leaders should use a mix of leadership styles (transformational as well as transactional) to achieve their visions. 


\section{References}

Aarons, G.A. (2006). Transformational and transactional leadership: association with attitudes toward evidence-based practice, Psychiatry Serv., 57(8), 1162-1169.

Achilles, A., Armenakis, J. B., Bernerth, J. P., Pitts, H., \& Jack, W. (2007). Organizational change recipients' beliefs scale: Development of an assessment instrument. The Journal of Applied Behavioral Science, 43(4), 481-505.

Antonakis, J., Avolio, B.J., \& Sivasubramaniam N. (2003). Context and leadership: an examination of the nine-factor full-range leadership theory using the Multifactor Leadership Questionnaire. The Leadership Quarterly, $14,261-295$.

Armenakis, A.A., \& Harris, S. G. (2002). Crafting a change message to create transformational readiness, Journal of Organizational Change Management, 15(2), $169-183$.

Armenakis, A.A. Pitts, J. P. Bernerth, J. B., \& Walker, H. J (2007). Organizational Change Recipients' Beliefs Scale. The Journal of Applied Behavioral Science 43(4):481-505.

Avolio, B. J., \& Bass, B. M. (2002). Developing potential across a full range of leadership: Cases on transactional and transformational leadership. New Jersey: Lawrence Erlbaum Associates Publishers.

Avolio, B. J., Bass, B. M., \& Jung, D. I. (1999). Re-examining the components of transformational and transactional leadership using the Multifactor Leadership Questionnaire. Journal of Occupational and Organizational Psychology, 72(4), 441-462.

Avolio, B., and Bass, B. (2004). Multifactor leadership questionnaire (third edition manual and sampler set). Mind Garden, Inc.

Avolio, B.J., \& Yammarino, F.J. (2002), Transformational and charismatic leadership: The road ahead. Oxford: Elsevier Science.

Bartunek, J., Rousseau, D., Rudolph, J., \& DePalma, J. (2006). On the receiving end: Sensemaking, emotion, and assessments of an organizational change initiated by others. The Journal of Applied Behavioral Science, 42, 182-206.

Bass, B. M. (1990). From Transactional to Transformational Leadership: Learning to Share the Vision. Organizational dynamics. 18 (3), 19-32.

Bass, B. M. (1997). Does the transactional-transformational leadership paradigm transcend organizational and national boundaries? American psychologist, 52(2), 130-139. 
Bass, B. M., \& Steidlmeier, P. (1999). Ethics, character, and authentic transformational leadership behavior. The Leadership Quarterly, 10(2), 181-217.

Bass, B. M., \& Avolio, B. J. (1995). MLQ multifactor leadership questionnaire, Leader form, rater form, and scoring. Palo Alto, CA: Mind Garden.

Bass, B.M., \& Riggio, R. (2006). Transformational Leadership. (2nd ed.) New Jersey: Lawrence Erlbaum Associate, Inc.

Bekele Shibru, \& Darshan, G.M. (2011). Effects of transformational leadership on subordinate job satisfaction in leather companies in Ethiopia. International Journal of Business Management and Economics. Research, 2(5), 284-296.

Bhattacherjee, A. (2012). Social science research: Principles, methods, and practices. Florida: University of South Florida.

Bogler, R. (2001). The influence of leadership style on teacher job satisfaction. Educational Administration Quarterly, 37(5), 662-683.

Buon, T. (2014). The leadership coaches. London: Hodder \& Stoughton.

Burns, J. M. (1978). Leadership. New York: Harper and Row.

Cohen -Mark Swerdlik, R.J (2006). Psychological testing and assessment: An introduction to tests and measurement ( $7^{\text {th }}$ ed.). NY: The McGraw-Hill Companies, Inc.

David, A. M., Nelson, D. A., \& Quick, J. C. (1998). The stress of organizational change: a dynamic process model. Applied Psychology, 47, 219-232.

Dionne, S.D., Yammarino, F.J., Atwater, L.E., \& Spangler, W.D. (2004). Transformational leadership and team performance. Journal of Organizational Change Management,17(2), 177-193.

Eisenberger, R., Huntington, R., Hutchison, S., \& Sowa, D. (1986). Perceived organizational support. Journal of Applied Psychology, 71(3), 500-507.

Ellickson, M. (2002). Determinants of job satisfaction of municipal employees. Public Personnel Management, 31(3), 343-358.

Emery, C.R., \& Barker, K.J. (2015). The effect of transactional and transformational leadership styles on the organizational commitment and job satisfaction of customer contact personnel. Journal of Organizational Culture, Communication \& Conflict, 11(1), 77-90.

Epitropaki, O., \& Martin, R. (2005b). The moderating role of individual differences in the relationship between transformational/transactional leadership perceptions and organizational identification. The Leadership Quarterly, 16(4), 569-589. 
Befekadu Zeleke and Belayneh Kifle

Gilley, A., McMillan, H. S., \& Gilley, J. W. (2009b). Organizational Change and Characteristics of Leadership Effectiveness. Journal of Leadership \& Organizational Studies, 16(1), 38-47.

Esayas Dendir, (2013). Factors affecting employee turnover at Ethiopian Electric Power Corporation (EEPCo) [unpublished master thesis]. Addis Ababa University.

Fikadu Mulugeta (2010). The Relationship between Leadership Style and Staff Job Satisfaction at the College of Education, Addis Ababa University. The International Journal of Education, 30 (1).

Fry, L.W., \& Slocum, J. (2008). Maximizing the triple bottom line through a strategic scorecard business model of spiritual leadership. Organizational Dynamics, 31(1), 86-96.

Fry, L.W. and Matherly, L.L. (2006). Spiritual leadership and organizational performance: An exploratory study. Precision Management Institute.

Glasby, J., \& Lester, H. (2004). Cases for change in mental health: partnership working in mental health services. Journal of Interprofessional Care, 18(1), 7-16.

Hair, J.F., Black, W.C., Babib, B.J., Anderson, R.E., \& Tatham, R.L. (2006): Multivariate Data Analysis (6 ${ }^{\text {th }}$ ed.). NJ: Pearson-Prentice Hall.

Hassan, E.M. (2019). The role of leadership style in organizational change management: A literature review. Journal of Human Resource Management, 7(1), 18-31.

Hui, C., \& Lee, C. (2000). Moderating effects of organization-based self-esteem on organizational uncertainty: Employee response relationships. Journal of Management, 26(2), 215-232.

Humidifier, F., (2010). A study of the relationship between leadership styles and employee job satisfaction at Islamic Azad University Branches in Tehran, Iran. AU-GSB e-Journal., 3, 45-58.

Herold, D.M., Fedor, D.B., Caldwell, S., \& Liu, Y. (2008). The effects of transformational and change leadership on employees' commitment to a change: a multilevel study. Journal of Applied Psychology, 93(2), 346-357.

Herzberg F. (1976). The managerial choice, to be efficient and to be human. Homewood. IL: Dow Jones-Irwin.

Holt, A.L., \& Brenner, S.O. (2015). Leadership style and the process of organizational change. Leadership \& Organization Development Journal, 36(1), 2-16. 
Holten, A. L., \& Brenner, S. O. (2015). Leadership style and the process of organizational change. Leadership \& Organization Development Journal, 36(1), 2-16.

Innstrand, S. T., Espnes, G. A., \& Mykletun, R. (2004). Job stress, burnout and job satisfaction: An intervention study for staff working with people with intellectual disabilities. Journal of Applied Research in Intellectual Disabilities, 17, 119-126.

Jansen, J. J., Vera, D., \& Crossan, M. (2009). Strategic leadership for exploration and exploitation: The moderating role of environmental dynamism. The Leadership Quarterly, 20(1), 5-18.

Kavanagh, M.H., \& Ashkanasy, N.M (2006). The impact of leadership and change management strategy on organizational culture and individual acceptance of change during a merger. British Journal of Management. 17, (S1) S81-S103 DOI 10.1111/j.1467-8551.

Kieselbach, T., Bagnara, S., Elo, A.-L., Jefferys, S., Joling, C., Kuhn, K., Nielsen, K., Popma, J., Rogovsky, N., Sahler, B., Triomphe, C.E., \& WiderszalBazyl, M. (2009). Health in restructuring innovative approaches and policy recommendations (HIRES). Muenchen: Rainer Hampp Verlag.

Koech, P. M., \& Namusonge, G. S. (2012) The effect of leadership styles on organizational performance at State Corporations in Kenya. International Journal of Business and Commerce. 2(1), 1-12.

Langton, N. S., \& Robbins, P. (2006). Fundamentals of organizational behavior. Toronto: Pearson Education Canada.

Lee, H.-C., \& Chuang, T.-H. (2003). The impact of leadership styles on job stress and turnover intention-Taiwan insurance industry as an example. REFER GROUP ONE.

Lok, P., \& and Crawford, J. (2004). The effect of organizational culture and leadership style on job satisfaction and organizational commitment: A crossnational comparison. Journal of Management Development, 23(4), 321-338.

Marks, M., \& Printy, M. (2003) Principal leadership and school performance: An integration of transformational and instructional leadership. Educational Administration Quarterly, 39, 370-397.

McGuire, D., \& Hutchins, K. (2006). A Machiavellian analysis of organizational change. Journal of Organizational Change Management,19, 199-209.

McKinnon, L.J., Harrison, L.G., Chow, W.C., \& Wu, A. (2003), Organizational culture: association with commitment, job satisfaction, propensity to remain and information sharing in Taiwan. International Journal of Business Studies, 11(1), 25-44. 
Befekadu Zeleke and Belayneh Kifle

Miller, D. (2002). Successful change leaders: What makes them? What do they do that is different? Journal of Change Management, 2(4), 359-368.

Montgomery, D.C., Peck, E.A., \& Vining, G.G. (2001). Introduction to linear regression analysis $\left(3^{\text {rd }} \mathrm{ed}\right)$., New York: Jon Wiley and Sons.

Morales, V.J., Barrionuevo, M.M., \& Gutiérrez, L.G. (2012). Transformational leadership influence on organizational performance through organizational learning and innovation. Journal of Business Research, 65,1040-1050.

Mosadegh, M.R, A., \& Hossein Y. M. (2006). A study of the relationship between managers' leadership style and employees' job satisfaction. Leadership in Health Services, 19(2),11-28.

Mugenda, A. G., \& Mugenda, O.M. (2003). Research methods; Qualitative and quantitative approaches. Nairobi: Kenya Acts Press.

Nanda, A. (1999). Implementing organizational change, in M. P. Cunha, \& C. A. Marques (Eds.) Readings in organization science: organizational change in changing context (pp. 489-522). Lisboa: ISPA.

Nazarian, A., Soares, A., \& Lottermoser, B. (2017). Inherited organizational performance? The perceptions of generation $\mathrm{Y}$ on the influence of leadership styles. Leadership \& Organization Development Journal, 38(8), 1078-1094.

Nebiat Negussie Corsalini \& Asresash Demissie (2013). Relationship between leadership styles of nurse managers and nurses' job satisfaction in Jimma university specialized hospital. Ethiopian Journal of health sciences, 23(1), 49-58.

Nicholson., W.D. (2007). Leading where it counts?: An investigation of the leadership styles and behaviors that define college and university presidents as successful fundraisers. International Journal of Educational Advancement, 7(4)

Noblet, A., Rodwell J., \& McWilliams, J. (2006). Organizational change in the public sector: Augmenting the demand-control model to predict employee outcomes under New Public Management. Work \& Stress, 20(4), 335-352

Northouse, P. G. (2013). Leadership, theory, and practice (5th ed.). CA: Sage Thousand Oaks.

Northouse, P. G. (2016). Leadership: Theory and practice (7th ed.). Thousand Oaks, CA: Sage.

Ojokuku, R., Odetayo, T., \& Sajuyigbe, A. (2012). Impact of leadership style on organizational performance: a case study of Nigerian banks. American Journal of Business and Management, 1(4), 202-207. 
Oreg, S., Vakola, M., \& Armenakis, A. (2011). Change recipients' reactions to organizational change, The Journal of Applied Behavioral Science, 47(4), 461-524.

Ozer, F., \& Tinaztepe, C. (2014). Effect of strategic leadership styles on firm performance: A study in a Turkish SME. Social and behavioral sciences, $150,778-784$.

Rafferty, A. E., \& Griffin, M. (2006). Perceptions of organizational change: A stress and coping perspective. Journal of Applied Psychology, 91(5), 11541162.

Rafferty, A.E., \& Griffin, M.A. (2006). Perceptions of Organizational Change: A Stress and Coping Perspective. Journal of Applied Psychology, 91,(5), 1154 -1162 .

Robert, J. Bies, R.J., \& Shapiro, D. L. (1987). Interactional fairness judgments: The influence of causal accounts. Social Justice Research,1,199-218.

Robert R. H. (2000). Does revising the intrinsic and extrinsic subscales of the Minnesota satisfaction questionnaire short form make a difference? Educational and Psychological Measurement, 60(2), 255-270.

Saleem, H. (2015). The impact of leadership styles on job satisfaction and mediating role of perceived organizational politics. Social and Behavioral Sciences, 172, $563-569$.

Schein, E.H. (2004). Organizational culture and leadership. San Francisco: Jossey-Bass.

Shim, S., Lusch, R., \& O'Brien, M. (2002). A hierarchical model of values, leadership, job satisfaction, and commitment: Human resources management implications for the retail industry. Journal of Marketing Channels, 10(1), 65-87.

Simons, D.J. (Ed.). (2000). Change blindness and visual memory: A Special issue of visual cognition. Hove: Psychology Press

Skakon, J., Nielsen, K., Borg, V., \& Guzman, J. (2010). Are leaders' well-being, behaviors, and style associated with the affective well-being of their employees? A systematic review of three decades of research. Work and Stress, 24 (2),107-139.

Smith, I. (2005). Achieving readiness for organizational change. Library Management, 26(6/7), 408-412.

Spector, P. E. (1985). Measurement of human service staff satisfaction: Development of the Job Satisfaction Survey. American Journal of Community Psychology, 13(6), 693-713. 
Befekadu Zeleke and Belayneh Kifle

Stone, G.A, Russell, R.F., \& Patterson, K. (2003). Transformational versus servant leadership: a difference in leader focus. Leadership \& Organization Development Journal. 25(4), 349-361.

Tickle, E.L., J. Brownlee, \& Nailon, D. (2005). Personal epistemological beliefs and transformational leadership behaviors. Dalam Journal of Management Development, 24,706-720.

Tourish, D., \& Pinnington, A. (2002). Transformational leadership, corporate cultism, and spirituality. Human Relations, 55, (2),147-172.

VGarcía-Morales, V.J. Jiménez-Barrionuevo, M.M., \& Gutiérrez-Gutiérrez, L. (2012). Transformational leadership influence on organizational performance through organizational learning and innovation. Journal of Business Research, 65, (7), 1040-1050.

Voon, M.L., Lo, M.C., Ngui, K.S., \& ve Ayob, N.B., (2011). The influence of leadership styles on employees job satisfaction in public sector organizations in Malaysia. International Journal of Business, Management and Social Sciences, 2(1), 24-32.

Wilderom C.P.M., Berg D.V., \& Peter T. (2004). Defining, measuring, and comparing organizational cultures. Internal Association for Applied Psychology, 53(4), 570-582.

Zervas, C., \& Lassiter, D. (2007). Leadership style: Is there 'one best', or is flexibility worth developing? Leadership Advantage LLC. 